\title{
Carcinogen Switching NQ01 Gene Polymorphism Study to Find Out the Risk Population in Vindhyan Region
}

\author{
Snehlata pandey ${ }^{1 *}$ and Sanjeev dubey ${ }^{2}$ \\ ${ }^{1}$ Center of Biotechnology studies school of Environmental Biology, India \\ ${ }^{2}$ Department of Botany, Government Model Science College, India
}

Submission: February 02, 2018; Published: September 04, 2018

*Corresponding author: Snehlata pandey, Center of Biotechnology studies school of Environmental Biology APSU Rewa M.P. (486001) India;

Email: snehlatapandey23@gmail.com

\begin{abstract}
The NQ01 is a gene catalyses an enzyme capable of maintaining quinones in their reduced form, therefore detoxify them. DT-diphorase (NQ01) converts toxic benzoquinone into hydroquinone in an incumbent two electron reduction. Only two polymorphic variants of NQ01 have been identified, a C-to-T change at nucleotide 609 yields a serine substitution and a T -to-C change at nucleotide 464 results in tryptophan replacement of Arginine. Some synthetic antioxidants such as Butyrate Hydroxyanisole and extracts of cruciferous vegetables, including broccoli have been emerges to be a potent inhancers of NQ01. This inhancibility has led to the suggestion that NQ01 can play an possible role in cancer chemo-prevention and therapy.
\end{abstract}

Keywords: Carcinogen switching, NQ01, Polymorphism, PCR, RFLP, Genotyping

Abbreviations: PAH: Polycyclic Aromatic Hydrocarbon; NQ01: DT-diphorase; HNSCC: Head and Neck Squamous Cell Carcinoma; DNA: Deoxyribonucleic Acid; PCR: Polymerase Chain Reaction; MW: Molecular Weight

\section{Introduction}

The NQO1 is an important carcinogen metabolizing gene, as responsible for the metabolism of highly ubiquitous environmental carcinogen like Polycyclic Aromatic Hydrocarbon $(\mathrm{PAH})$ which is also the most lethal constituent of cigarette smoke. The genotype and allelic frequencies of three Polycyclic aromatic Hydrocarbon $(\mathrm{PAH})$ metabolizing genes were determined in a sample of typical population, which were stratified into three groups (Hindu, Muslim and Tribal) based on their ethnicity. DTdiphorase is an enzyme which has known because of its ability to detoxify a number of natural and Synthetic Compounds and also to activate certain anti- cancer factors [1]. Among Northern Europeans and Caucasian Americans, the gene frequency is 0.79 for the wild-type allele and 0.21 for the mutated allele [2,3]. DT-diphorase (NQ01) converts toxic benzoquinone into hydroquinone in an obligate two electron reduction [4].

This reaction is in competition with one-electron reduction reactions by Cytochrome P-450, producing the semiquinones, which generate free radicals and reactive oxygen species via redox cycling. The NQO1 is capable of maintaining these quinones in their reduced form, therefore detoxify them $[5,6]$. Only two polymorphic variants of NQO1 have been identified, a C-to-T change at nucleotide 609 yields a serine substitution and a $\mathrm{T}$-to-C change at nucleotide 464 results in tryptophan replacement of Arginine. The C 609 T effectively inactivates the enzyme due to decreased catalytic activity and stability of NQO1 protein $[7,8]$.

The frequency of the mutated allele is known to be slightly higher among African Americans and considerably higher among Hispanics and Asians [9]. NQO1 enzyme activity is found to be normal in individuals with wild-type alleles. It is variably reduced in individuals who are hetero-zygotes for the polymorphism [10]. The NQ01 protein and activity are absent in those who are homozygous for the point mutation [11]. It is reported that inhibition of NAD (P) H: quinone oxidoreductase 1 (NQ01) activity by dicoumarol induces degradation of p53, indicating that NQ01 plays a role in p53 stabilization, which has a crucial role in cell cycle regulation [12]. In various studies NQ01 null alleles has shown to be associated with benzene related leukemia, cancer of lung, and colon. A study suggests that NQ01 can modulate the susceptibility for breast cancer [13-16]. Chang Gun Cho and co - workers concluded that NQ01 139Arg allele were associated with tobacco dose-dependent increase 


\section{Advances in Biotechnology \& Microbiology}

in risk of head and neck squamous cell carcinoma (HNSCC) and NQ01 genotype polymorphisms may play an important role in the development of smoking related HNSCC [17]. However, Hongwei Chen and coworkers have found no relation between NQO1 null allele and lung cancer [18]. But this not renders the significance of NQ01. It is also a highly inducible enzyme, synthetic antioxidants such as Butyrate Hydroxyanisole and extracts of cruciferous vegetables, including broccoli have been shown to be potent inducers of NQ01. This inducibility has led to the suggestion that NQO1 can play an important role in cancer chemo-prevention and therapy.

\section{Material and Methods}

\section{Study population}

In our study we have selected the vindhyan region, the heart land of India. This is constructed by four district of Madhya Pradesh and is the oldest habitat of man kind. The Kol, Gond, Bhil and Baiga are the native tribe of this region. Modern population is dominated by Hindu and Mohammedan religions. We have selected the 409 normal healthy individuals who were occupationally (or non-occupationally PAHs (Polycyclic Aromatic Hydrocarbons) exposed. All the subjects were the regular resident of the Vindhyan region (Table 1).

Table 1: Clinical feature of study population.

\begin{tabular}{|c|c|c|c|}
\hline Clinical feature & Hindu & Muslim & Tribal \\
\hline Total no. & 311 & 25 & 73 \\
\hline $\begin{array}{c}\text { Sex ratio } \\
\text { (Male:Female) }\end{array}$ & $136: 175$ & $9: 16$ & $34: 39$ \\
\hline Age & $33.43 \pm 13.96$ & $35.24 \pm 15.68$ & $35.52 \pm 15.30$ \\
\hline Mean \pm SD & 32 & 32 & 30 \\
\hline Median & Nov-73 & $16-73$ & $16-74$ \\
\hline Age range & & & \\
\hline Smoker (No.) & 39 & 8 & 16 \\
\hline
\end{tabular}

\section{Blood collection and plasma/serum separation}

Approx. 5ml. of Venous blood samples of each individual were collected in storage vials containing EDTA as anticoagulant (50 $\mu$ l. EDTA for $1 \mathrm{ml}$. blood). Immediately, plasma and serum from the respective vacutainers were separated by centrifuging the tubes at $1000 \mathrm{rpm}$ for $10 \mathrm{~min}$ at $4{ }^{\circ} \mathrm{C}$.

\section{Deoxyribonucleic acid (DNA) isolation}

Genomic DNA was extracted from whole blood by the modification of salting out procedure described by Miller [7].

\section{Detection of NQO 1 (Hinf I) polymorphism via PCR- RFLP}

A C-to-T change at nucleotide 609 in NQO 1 genes yields a serine substitution. Which create a Hinf I cleavage site. Primer was designed to amplify $172 \mathrm{bp}$ sequence to study this polymorphism.

\section{Genotyping}

Genotyping was carried out by polymerase chain reaction (PCR) and restriction enzyme digestion. The NQO1 polymorphism was detected using the following primers: NQO Hinf I F- 5'AAG CCC AGA CCA ACT TCT3' and NQO Hinf I R- 5'ATT TGA ATT CGG GCG TCT GCT G3'. The oligonucleotides sequences (primers) used were those described by Jianhui Zhang et al (171): The PCR was carried out in a final volume of $25 \mu \mathrm{l}$, containing $100 \mathrm{ng}$ of genomic DNA(4-5 $\mu \mathrm{l}), 2.5 \mu \mathrm{l}$ of $10 \mathrm{X}$ Taq polymerase buffer (10 mM Tris $\mathrm{HCl} \mathrm{pH} \mathrm{8.8,} 50 \mathrm{mM} \mathrm{KCl,} 1.5 \mathrm{mM} \mathrm{MgCl} 2,0.01 \%$ gelatin, $0.005 \%$ Tween-20, 0.005\% NP-40; final concent ration 1X; Genetix Biotech Asia Pvt. Ltd., India), $1 \mu \mathrm{l}$ of $10 \mathrm{mM}$ dNTPs (Banglore Genei, Bangalore, India), $1 \mu \mathrm{l}$ of $25 \mathrm{pmol} / \mu \mathrm{l}$ of secific forward and reverse primers and $1 \mu \mathrm{l}$ of unit of $1 \mathrm{U} / \mu \mathrm{l}$ Red Taq DNA polymerase (Bangalore genei).

Thermal profile used for the amplification of desired segment of gene was as follows: Initial denaturation at $95^{\circ} \mathrm{C}$ for $5 \mathrm{~min}$ and 30 cycles of denaturation at $94^{\circ} \mathrm{C}$ for $45 \mathrm{Sec}$, annealing at 62.9 ${ }^{\circ} \mathrm{C}$ for $45 \mathrm{sec}$ and extension at $72{ }^{\circ} \mathrm{C}$ for $1 \mathrm{~min}$, followed by final extension at $72{ }^{\circ} \mathrm{C}$ for $07 \mathrm{~min}$. PCR products were separated on $2 \%$ agarose gel $(2 \% \mathrm{w} / \mathrm{v}$, Sigma) using a $100 \mathrm{bp}$ molecular weight (MW) marker to confirm the PCR product size of $172 \mathrm{bp}$. For restriction digestion of the $\mathrm{C}$-to-T substitution at Nucleotide 609 non-coding region, which creates an Hinf I restriction enzyme cleavage site.

The reaction mix included 0.2 of $10,000 \mathrm{U} / \mathrm{ml}$ Hinf I restriction enzyme (final concentration $2.5 \mathrm{U}$ ), 2.5 of 10X GENAI Buffer c (final concentration 1X; $50 \mathrm{mM}$ potassium acetate, $20 \mathrm{mM}$ Tris acetate, $10 \mathrm{mM}$ magnesium acetate, $1 \mathrm{mM}$ DTT, pH 7.9(' 10.0 of PCR product and 10 of sterile water. Reaction was incubated for $24 \mathrm{hrs}$ at $37{ }^{\circ} \mathrm{C}$ for complete digestion. 10 of digested PCR product was loaded on 2\% Agarose gel. Electrophoresis was done at $80 \mathrm{~V}$ in $1 \mathrm{X}$ Tris-borate EDTA buffer $(89 \mathrm{mM}$ Tris $\mathrm{pH} 7.6$, 89 mM Boric acid, 2 mM EDTA pH 8.0) buffer.) A 100 bp gene DNA ladder (genetix india) was run concurrently as molecular weight marker. The gel was than stained with ethidium bromide $(10 \mathrm{mg} / \mathrm{ml})$. The products were visualized using an ultraviolet trans illuminator. The gel picture was captured using a digital camera and gel documentation software (Vilber Lourmate, Cedex I , France).

\section{Statistical analysis}

Statistical analysis was done by comparing the distribution of genotype frequencies and allele frequencies for all polymorphisms in all groups of study subjects. The proportions of different genotypes for a gene in a population are known as genotype frequencies. The proportion of a genotype in a sample will be the ratio of the number of individuals having that genotype of the total number of individuals in the sample. The proportions of different alleles for a gene present in a population are known as allele frequencies. The proportion of an allele in a sample will be the ratio of number of occurrences of the investigated allele in the population to the total number of alleles. Data was analyzed using Microsoft Excel 2002, Microsoft Corporation and graphPad Instat program (GraphPad Software, San Diego California USA, Copyright 1992-1998 GraphPad Software Inc. (www.graphpad. com). 


\section{Advances in Biotechnology \& Microbiology}

\section{Results}

\section{Hardy - Weinberg equilibrium}

The genotype frequencies of each study group were tested to be in accordance with hardy - Weinberg equilibrium using chi square test for independence. All the calculated values were compared with tabulated values and found that all the frequencies were in Hardy- Weinberg equilibrium (Table 2).\

Table 2: Values of Chi square test for Hardy-Weinberg equilibrium for NQO1 genes in study population.

\begin{tabular}{|c|c|c|c|}
\hline \multirow{2}{*}{$\begin{array}{c}\text { Gene } \\
\text { polymorphism }\end{array}$} & \multicolumn{3}{|c|}{ Study Groups $(\chi 2$ Values) } \\
\cline { 2 - 4 } & Hindu & Muslims & Tribal's \\
\hline NQ01 Hinf I & 0.000255 & 0.11347 & 0.151241 \\
\hline
\end{tabular}

Determination of NQ01 Hinf I polymorphism, genotypes / Alleles frequencies and their association between study groups

In our investigation the polymorphism of NQO1 genes studied by PCR - RFLP. The C to T substitution at nucleotide 609 creates the restriction site for Hinf I. The PCR products of Wild type allele (CC) were $172 \mathrm{bp}$ long and were un-digestable by Hinf I at standard condition. Heterozygous condition (CT) was appeared as the production of $172 \mathrm{bp}, 131 \mathrm{bp}$ and $41 \mathrm{bp}$ long DNA fragment after the digestion with Hinf I. The Null alleles (TT) were detected as the $131 \mathrm{bp}$ and $41 \mathrm{bp}$ long fragments after digestion with Hinf I at standard condition. The genotype frequency (in $\%$ of CC, CT and TT Genotypes scored 69\%, 24\% and 07\% respectively in hindues. In Muslims it is recorded CC $=68 \%, \mathrm{CT}=$ $20 \%$ and $\mathrm{TT}=12 \%$. In Tribal population genotype frequencies were found $\mathrm{CC}=70 \%, \mathrm{CT}=23 \%$ and $\mathrm{TT}=07 \%$ (Table 3 ) (Figures $1 \& 2)$. The association of genotype frequency distribution in all three groups (Hindu, Muslim and Tribals) were studied and as recorded, there is no statically significant differences exist as the $\chi 2$ and $P$ values were $\chi 2=0.7994(P=0.6705)$ between Hindu Muslim, $\chi 2=0.7042(\mathrm{P}=0.7032)$ between Muslim - Tribal and $\chi 2=0.05735(\mathrm{P}=0.9717)$ between Hindu - Tribals (Table 3).

Table 3: Frequency distribution and association of Genotype and allels of NQO1 genes in study groups.

\begin{tabular}{|c|c|c|c|c|c|c|}
\hline \multirow{3}{*}{$\begin{array}{c}\text { NQ01 genes } \\
\text { Genotypes }\end{array}$} & \multicolumn{6}{|c|}{ Study Groups } \\
\hline & \multicolumn{2}{|c|}{ Hindu } & \multicolumn{2}{|c|}{ Muslim } & \multicolumn{2}{|c|}{ Tribal } \\
\hline & No. & $\%$ & No. & $\%$ & No. & $\%$ \\
\hline $\mathrm{CC}$ & 213 & 69 & 17 & 68 & 51 & 70 \\
\hline СT & 75 & 24 & 5 & 20 & 17 & 23 \\
\hline $\mathrm{TT}$ & 23 & 7 & 3 & 12 & 5 & 7 \\
\hline \multicolumn{5}{|c|}{$\chi 2$ Values } & \multicolumn{2}{|c|}{ P- Values } \\
\hline Hindu-Muslim & 0.7994 & & & & 0.6705 (NS) & \\
\hline Muslim- Tribal & 0.7042 & & & & $0.7032(\mathrm{NS})$ & \\
\hline Hindu-Tribal & 0.05735 & & & & $0.9717(\mathrm{NS})$ & \\
\hline Allels & \multicolumn{2}{|c|}{ Hindu Frequency \% } & \multicolumn{2}{|c|}{ Muslim Frequency \% } & \multicolumn{2}{|c|}{ Tribal Frequency \% } \\
\hline $\mathrm{C}$ & \multicolumn{2}{|c|}{81} & \multicolumn{2}{|c|}{78} & \multicolumn{2}{|c|}{82} \\
\hline $\mathrm{T}$ & \multicolumn{2}{|c|}{19} & \multicolumn{2}{|c|}{22} & \multicolumn{2}{|c|}{18} \\
\hline \multicolumn{7}{|c|}{ P- Values (Fisher's exact test) } \\
\hline Hindu - Muslim & \multicolumn{6}{|c|}{0.7264 (NS) } \\
\hline Muslim - Tribal & \multicolumn{6}{|c|}{0.5963 (NS) } \\
\hline Hindu - Tribal & \multicolumn{6}{|c|}{1.0000 (NS) } \\
\hline
\end{tabular}

NS $=$ Non Significant,$P=$ Probability

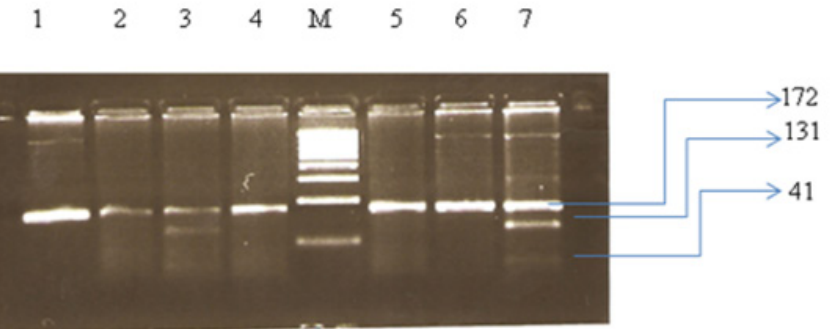

Lane $1,2,4,5 \& 6=$ Wild Type $(\mathrm{CC})$

Lane 3 \& $7=$ Heterozygous (CT)

$\mathrm{M}=100 \mathrm{bp}$ Ladder

Figure 1: NQO1 Hinf I Gel Image. 

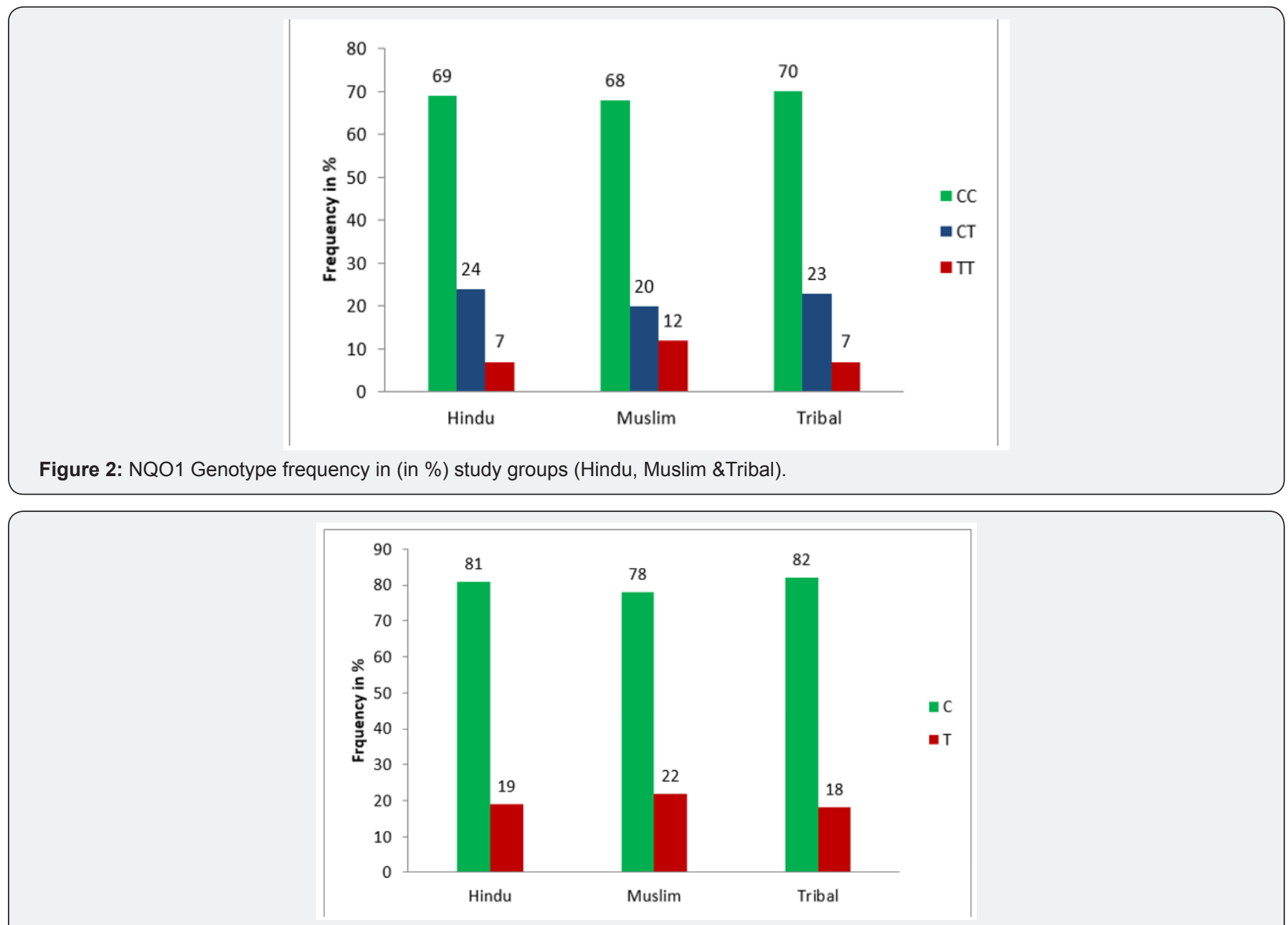

Figure 3 : NQO1 Allelic frequency in (in \%) study groups (Hindu, Muslim \&Tribal).

The distribution of $\mathrm{C}$ and $\mathrm{T}$ alleles in various groups were scored $\mathrm{C}=81 \%$ and $\mathrm{T}=19 \%$ in Hindues, $\mathrm{C}=78 \%$ and $\mathrm{T}=22 \%$ in Muslims and $\mathrm{C}=82 \%, \mathrm{~T}=18 \%$ in Tribal population (Table 3) (Figure 3). The association between Allelic distribution in all three groups were studied by Fisher's exact test and values obtained were, $\mathrm{P}=0.7264$ between Hindu - Muslim, $\mathrm{P}=0.5963$ between Muslim - Tribal and P $=1.0000$ between Hindu Tribal. All the values were non significant which showed that the frequency distribution of $\mathrm{C}$ and $\mathrm{T}$ allele in all three groups were statically not different (Table 3 ).

\section{Discussion}

The population of India is always being the part of research due to its large population, unique culture and diversity. Indian population can be distinguished as the castes, tribes and religious communities. Tribes represent approx. $8.2 \%$ of the total population of India. There are currently about 530 tribal groups in India. Madhya Pradesh (MP) is the second largest Indian state by area, is located in the central part and is homeland of several caste and tribal groups. In past three decades the information about carcinogen metabolism has been improved. Due to this information the interest has grown about study of polymorphism among carcinogen activating and de-activating genes. In this respect we have conducted a broad polymorphism screening study in population of Vindhyan Region.

The total 409 individuals were screened for the NQ01 Hinf I polymorphism, in which 311 individuals were Hindu, 25 individuals were Muslim and 73 individuals were Tribal. The NQ01 Hinf I genotype distribution pattern varies by ethnicity in world human population. In our study population (Hindu, Muslim and Tribal) it was observed as CC $=69 \%$, CT $=24 \%$ and TT $=07 \%$ in Hindu, which was found corresponding to Tribal population where $\mathrm{CC}=70 \%, \mathrm{CT}=23 \%$ and was $\mathrm{TT}=07 \%$ observed. There was a slight difference scored between these two groups and Muslim as genotype frequencies observed were $\mathrm{CC}=68 \%$, CT $=20 \%$ and $\mathrm{TT}=12 \%$ in Muslim, which showed the slight increase in homozygosity and higher frequency of TT (Mutant) genotype than Hindu and Tribal. The NQ01 Hinf I genotype frequency of our population did not statically different with reported in Maharastrian Indians where CC = $52.3 \%, \mathrm{CT}=42.48$ and $\mathrm{TT}=5.18 \%$ scored [19]. But an increase in Heterozygosity observed in Maharastrian Indian than our population. It could be due to random mixing of various ethnic groups in Maharastrian population in modern age. But increase in heterozygosity surprised us because the marriage between the close relatives in Maharastrian is common. 
The frequencies observed in our population did not match with the Caucasian, Chinese and Koreans where frequencies reported were $\mathrm{CC}=79 \%, \mathrm{CT}=16 \%$ and $\mathrm{TT}=05 \%$ in Caucasian [20], $\mathrm{CC}=34 \%, \mathrm{CT}=49.7 \%$ and $\mathrm{TT}=16.3 \%$ in Chinese and CC $=94.5 \%, \mathrm{CT}=5.2 \%$ and $\mathrm{TT}=0.3 \%$ in Koreans $[21,22]$. This showed that these populations are distinct from our study population. The Swedish population showed a slight difference with our population where the $\mathrm{CC}=69.4, \mathrm{CT}=28.9 \%$ and $\mathrm{TT}=$ $1.7 \%$ scored [23]. But the distribution of TT (Mutant) allele was less in Swedish than our population. The genotype frequencies of our population also match with the population of different Iranian ethnic groups [24], when compared, where the $\mathrm{CC}=$ $59.5 \%, \mathrm{CT}=31 \%$ and $\mathrm{TT}=9.5 \%$ in Fars, CC $=64 \%, \mathrm{CT}=24 \%$ and $\mathrm{TT}=12 \%$ in Mazzandarani and CC $=69 \%, \mathrm{CT}=28.6 \%$, TT $=$ $2.4 \%$ in Turk recorded. But an Increase in TT (Mutant) genotype was scored in our population and in Two Iranian ethnic groups (Fars and Mazzandarani) than Turk and other world population. The results were in agreement with the phenomena of common ancestry of Indian and Iranian population.

The allelic distributions were found in accordance with others finding in Caucasian population $(\mathrm{C}=81.1 \%$ and $\mathrm{T}=$ $18.9 \%$ [25], as there were no significant differences were calculated, where in our population it was recorded as $\mathrm{C}=81 \%$ and $\mathrm{T}=19 \%$ in Hindu, $\mathrm{C}=78 \%$ and $\mathrm{T}=22 \%$ in Muslim and in Tribal it was $\mathrm{C}=82 \%$ and $\mathrm{T}=18 \%$.

\section{Conclusion}

The significant differences were seen when results from our finding were compared with others finding in various Asian population, where the frequency of $\mathrm{C}$ allele were $57 \%$ and $\mathrm{T}$ allele were $43 \%$ calculated in previous finding by Kiyohara et al. [14], This difference were also evident when our results of our population compared with individual finding of Choi et al. [25] in Korean and Fowke et al. [26] in Chinese population, where the frequencies were recorded as $\mathrm{C}=58.5 \%$ and $\mathrm{T}=41.5 \%$ in Korean and frequency of $\mathrm{C}$ allele were scored $59.3 \%$ and $\mathrm{T}$ allele were scored $40.7 \%$ in Chinese. These results were not surprised us because in calculation of NQO1 Hinf I allele the Kiyohara et al. [14] did not included the frequencies of Indian population and his finding were solely based on the results from Korean, Chinese and Japanese population, which are totally distinct from our population and belongs to different race. This finding suggests that the Indian population can not co-related with whole Asian population.

\section{Acknowledgement}

I thank to all participants in this study work.

\section{References}

1. Duffy S, So A, Murphy TH (1998) Activation of endogenous antioxidant defenses in neuronal cells prevents free radical-mediated damage. J Neurochem 71(1): 69-77.

2. Wiencke JK, Spitz MR, McMillan A, Kelsey KT (1997) Lung cancer in Mexican- Americans and African-Americans is associated with the wild-type genotype of the $\mathrm{NAD}(\mathrm{P}) \mathrm{H}$ : quinone oxidoreductase polymorphism. Cancer Epidemiol Biomarkers Prev 6(2): 87-92.
3. Traver RD, Siegel D, Beall HD, Phillips RM, Gibson NW, et al. (1997) Characterization of a polymorphism in NADP(H): quinone oxidoreductase (DT diaphorase). Br J Cancer 75(1): 69-75.

4. Lind C, Cadenas E, Hochstein P, Ernster L (1990) DT-diaphorase: purification, properties, and function. Methods Enzymol 186: 287-301.

5. Kim K, Suk H (1999) Reduction of nitrosoarene by purified NAD(P) H-quinone oxidoreductase. J Biochem Mol Biol 32: 321-325.

6. Dinkova-Kostova AT, Talalay P (2000) Persuasive evidence that quinone reductase type 1 (DT-diaphorase) protects cells against the toxicity of electrophiles and reactive forms of oxygen. Free Radic Biol Med 29(3-4): 231-240.

7. Jaiswal AK (1991) Human NAD(P)H: quinone oxidoreductase (NQO1) gene structure and induction by dioxin. Biochemistry 30: 1064710653.

8. Jaiswal AK (2000) Regulation of genes encoding NAD(P)H:quinone oxidoreductases Free Radic Biol Med 29(3-4): 254-262.

9. Kelsey KT, Ross D, Traver RD, Christiani DC, Zuo ZF, et al. (1997) Ethnic variation in the prevalence of a common NAD(P)H quinone oxidoreductase polymorphism and its implications for anti-cancer chemotherapy. Br J Cancer 76(7): 852-854.

10. Ross D, Traver RD, Siegel D, Kuehl BL, Misra V, et al. (1996) A polymorphism in NAD(P)H:quinone oxidoreductase (NQO1): Relationship of a homozygous mutation at position 609 of the NQ01 cDNA to NQ01 activity. Br J Cancer 74(6): 995-996.

11. Traver RD, Rothman N, Smith MT, Yin SY, Hayes RB, et al. (1996) Incidence of a polymorphism in $\mathrm{NAD}(\mathrm{P}) \mathrm{H}$ : quinone oxidoreductase (NQ01). Proc Am Assoc Cancer Res 37: 278.

12. Gad Asher, Joseph Lotem, Rachel Kama, Leo Sachs, et al. (2002) NQO1 stabilizes p53 through a distinct pathway. Proc Natl Acad Sci U S A 99(5): 3099-3104.

13. Martyn T Smith (1999) Benzene, NQ01, and genetic susceptibility to cance. Proc Natl Acad Sci U S A 96(14): 7624-7626.

14. Kiyohara C, Yoshimasu K, Takayama K, Nakanishi Y (2005) NQ01, MPO, and the risk of lung cancer: A HuGE review. Genet Med 7(7): 463-478.

15. Begleiter A, Hewitt D, Maksymiuk AW, Ross DA, Bird RP (2006) A NAD(P)H:Quinone Oxidoreductase 1 Polymorphism Is a Risk Factor for Human Colon Cancer. Cancer Epidemiol Biomarkers Prev 15(12): $2422-2426$

16. Fowke JH, Shu XO, Dai Q Jin F, Cai Q, et al. (2004) Oral Contraceptive Use and Breast Cancer Risk: Modification by NAD (P) $\mathrm{H}$ :Quinone Oxoreductase (NQO1) Genetic Polymorphisms. Cancer Epidemiol Biomarkers Prev 13(8): 1308-1315.

17. Cho CG, Lee SK, Nam SY, Lee MS, Lee SW, et al. (2006) Association of the GSTP1 and NQ01 Polymorphisms and Head and Neck Squamous Cell Carcinoma Risk. J Korean Med Sci 21(6): 1075-1079.

18. Hongwei Chen, Annette Lum, Ann Seifried, Lynne R Wilkens, Le Marchand (1999) Association of the NAD(P)H:quinone Oxidoreductase 609C3T Polymorphism with a Decreased Lung Cancer Risk. Cancer Research 59: 3045-3048.

19. Saravana Devi S, Vinayagamoorthy N, Agrawal M, Biswas A, Biswas $\mathrm{R}$, et al. (2008) Distribution of detoxifying genes polymorphism in Maharastrian Population of central India. Chemosphere 70(10): 18351839.

20. Toncheva DI, Von Ahsen N, Atanasova SY, Dimitrov TG, Armstrong VW et al. (2004) Identification of NQO1 and GSTs genotype frequencies in Bulgarian patients with Balkan endemic nephropathy. J Nephrol 17(3): 384-389.

21. Zhang J, Schulz WA, Li Y, Wang R, Zotz R, et al. (2003) Association of NAD (P) H: quinone oxidoreductase 1 (NQ01) C609T polymorphism with esophageal squamous cell carcinoma in a German Caucasian and a northern Chinese population. Carcinogenesis 24(5): 905-909. 
22. Cho CG, Lee SK, Nam SY, Lee MS, Lee SW, (2006) Association of the GSTP1 and NQO1 polymorphisms and Head and Neck Squamous Cell Carcinoma Risk, J Korean Med Sci 21(6): 1075-1079.

23. Alexandrie AK, Nyberg F, Warholm M, Rannug A (2004) Influence of CYP1A1, GSTM1, GSTT1, and NQ01 Genotypes and Cumulative Smoking Dose on Lung Cancer Risk in a Swedish Population, Cancer Epidemiol Biomarkers Prev 13(6): 908-914.

24. Firouzeh Biramijamal, Mohammed Hossein Sanati, Mohammed Mahdi Banoei, Behnaz Bayat, Sareh Arjmand, et al. (2006)
Genetic polymorphism analysis of NAD(P)H: quinone oxidoreductase 1 in different Iranian ethnic groups. Current Science 91(8): 25.

25. Choi JY, Lee KM, Cho SH, Kim SW, Choi HY, et al. (2003) CYP2E1 and NQ01 genotypes, smoking and bladder cancer. Pharmacogenetics; 13(6): 349-355.

26. Fowke JH, Shu XO, Dai Q Shintani A, Conaway CC, et al. (2003) Urinary isothiocyanate excretion, brassica consumption, and gene polymorphisms among women living in Shanghai, China. Cancer Epidemiol Biomarkers Prev 12(12): 1536-1539.

\section{Your next submission with Juniper Publishers will reach you the below assets}

- Quality Editorial service

- Swift Peer Review

- Reprints availability

- E-prints Service

- Manuscript Podcast for convenient understanding

- Global attainment for your research

- Manuscript accessibility in different formats ( Pdf, E-pub, Full Text, Audio)

- Unceasing customer service

Track the below URL for one-step submission https://juniperpublishers.com/online-submission.php 